\title{
'Staring at the felony forest'
}

\section{De complexiteit van risicoprofilering nader in kaart gebracht ${ }^{*}$}

\author{
Tim Dekkers \& Maartje van der Woude
}

\section{Inleiding}

Het gebruik van risicoprofilering door (opsporings)instanties is een hot issue. Het systematisch selecteren en categoriseren van personen aan de hand van verschillende kenmerken door bijvoorbeeld de politie of luchtvaartmaatschappijen zorgt voor een hoop discussie. Waar de desbetreffende instanties doorgaans een verhoogde efficiëntie en effectiviteit door het gebruik van risicoprofielen benadrukken, ${ }^{1}$ wijzen critici op het gevaar van discriminatie, stigmatisering en daarmee juist inefficiëntie. ${ }^{2}$ Het recente debat rondom etnisch profileren door de Nederlandse politie - hiermee doelend op het selecteren van personen voor preventieve stops louter op basis van hun etniciteit en huidskleur - zoals tot stand gekomen naar aanleiding van een recent verschenen overzichtsrapportage van Amnesty International, ${ }^{3}$ is illustratief voor dit laatste standpunt.

Het gevaar van etnisch profileren wordt in discussies, zo ook in het voornoemde rapport van Amnesty International, dikwijls direct gerelateerd aan de uitbreiding van discretionaire bevoegdheden van opsporingsambtenaren en toezichthouders

* Tim Dekkers is junior onderzoeker bij het Instituut voor Strafrecht \& Criminologie van de Universiteit Leiden. Maartje van der Woude is daar universitair hoofddocent. Het aan het artikel ten grondslag liggende onderzoek is mede mogelijk gemaakt dankzij een financiële bijdrage van de Gratama Stichting en het Leids Universiteits Fonds.

1 E. Silver \& L.L. Miller, 'A cautionary note on the use of actuarial risk assessment tools for social control', Crime \& Delinquency 2002, 1, p. 138-161; B.E. Harcourt, Against Prediction: Profiling, Policing and Punishing in an Actuarial Age, Chicago: University of Chicago Press 2006a; M.A.H. van der Woude \& J.P. van der Leun, 'De Nederlandse veiligheidscultuur als katalysator voor etnisch profileren', Tijdschrift over Cultuur \& Criminaliteit 2013,2, p. 123-136.

2 S.H, Legomsky, The Ethnic and Religious Profiling of Noncitizens: National Security and International Human Rights, 25 B.C. Third World 2005, L.J. 161; Harcourt 2006a; B.E. Harcourt, Muslim Profiles Post 9/11: Is Racial Profiling an Effective Counterterrorist Measure and Does it Violate the Right to be Free from Discrimination?, Chicago: University of Chicago Law School 2006b; C. Lusane, 'Fightback: The Movement Against Racial Profiling in Europe', Souls: A Critical Journal of Black Politics, Culture, and Society 2008, 4, p. 374-389; Open Justice Society Initiative, Ethnic Profiling in the European Union: Pervasive, Ineffective, and Discriminatory, New York: Open Society Institute 2009; T. Ojanen, 'Terrorist profiling: human rights concerns', Critical Studies on Terrorism 2010, 2, p. 295-312; W. Press, 'To catch a terrorist: can ethnic profiling work?', Significance 2010, 4, p. 164-167.

3 Amnesty International, Proactief politieoptreden vormt risico voor mensenrechten: etnisch profileren onderkennen en aanpakken, Amsterdam: Amnesty International 2013. 
bij zogeheten proactieve controles. ${ }^{4}$ Voorbeelden van dergelijke proactieve controles zijn preventief fouilleren en identiteitscontrole. Deze uitbreiding gaat gepaard met een grotere zelfstandige beoordelingsvrijheid. Hierdoor zou het gevaar van profileren louter op basis van huidskleur op de loer liggen, zeker in het licht van het huidige politieke en maatschappelijke klimaat rondom criminaliteit en migratie en de toegenomen druk op de politie om zo efficiënt mogelijk te presteren. Het problematische aspect van risicoprofilering wordt gezocht in de subjectieve - en bij etnisch profileren daardoor discriminatoire - wijze waarop politieambtenaren en toezichthouders hieraan invulling zouden kunnen geven. Daarentegen wordt het gebruik van risicoprofielen vanuit de instanties die er daadwerkelijk mee werken doorgaans juist gepresenteerd als een middel om op een meer objectieve wijze tot beslissingen te kunnen komen. ${ }^{5}$ Of het werken met profielen ook daadwerkelijk objectief is, is nog maar de vraag. Zoals Rose ${ }^{6}$ benadrukt, blijft het toepassen van risicoprofielen en gestandaardiseerde meetsystemen toch mensenwerk. Het is daarmee gekoppeld aan een subjectief element.

Zoals Van der Woude en Van der Leun ${ }^{7}$ aangeven, is het onderzoek in Nederland naar etnisch profileren erg beperkt. De onderzoeken geven aanwijzingen tot zorg ten aanzien van etnisch profileren in Nederland, zeker tegen de achtergrond van een veranderend politiek en maatschappelijk klimaat, waarin criminaliteit en migratie dikwijls als nauw verwante begrippen worden gezien. Het beschikbare empirische materiaal is echter vooralsnog te beperkt en niet volledig om als basis voor harde conclusies te kunnen dienen. Op de onderzoeken van Çankaya ${ }^{8}$ en Kleijer-Kool ${ }^{9}$ na, ${ }^{10}$ belicht het aanwezige onderzoek naar etnisch profileren met name de perceptie van de burger. In hoeverre hebben burgers die te maken hebben gehad met (proactieve) controlebevoegdheden het idee dat zij louter zijn gestopt op basis van hun etnische kenmerken?

Wij willen niet ontkennen dat het in kaart brengen van de wijze waarop burgers het optreden van de politie waarderen belangrijk is met het oog op de legitimiteit

4 E.R. Muller e.a., Bestuur, recht en veiligheid: bestuursrechtelijke bevoegdheden voor openbare ordehandhaving en terrorismebestrijding, Den Haag: Boom Juridische uitgevers 2007; Q. Eijkman, 'Has the Genie Been Let Out of the Bottle? Ethnic Profiling in the Netherlands', Public Space: the Journal of Law and Social Justice 2010, 2, p. 1-21; J.P. van der Leun \& M.A.H. van der Woude, 'Ethnic profiling in the Netherlands? A reflection on expanding preventive powers, ethnic profiling and a changing social and political context', Policing and Society 2011, 4, p. 444-455; Van der Woude \& Van der Leun 2013.

5 A.J. Hoogstrate \& C.J. Veenman, Informatiegestuurde grenscontrole: verkenning ten behoeve van het gebruik van selectieprofielen in het kader van grensbeheer, Den Haag: Nederlands Forensisch Instituut 2012.

6 N. Rose, 'Governing risky individuals: The role of psychiatry in new regimes of control', Psychology and Law 1998, 2, p. 177-195.

7 Van der Woude \& Van der Leun 2013.

8 S. Çankaya, De controles van marsmannetjes en ander schorriemorrie: het beslissingsproces tijdens proactief politiewerk, Den Haag: Boom Lemma uitgevers 2012.

9 L. Kleijer-Kool, Multicultureel politiewerk, Den Haag: Boom Lemma uitgevers 2013.

10 Het onderzoek van Çankaya (2012) richt zich op de selectie door de politie op het gebied van proactieve controles tijdens hun surveillance. Het onderzoek van Kleijer-Kool (2013) gaat in op het bredere kader van multicultureel vakmanschap. Hierbij wordt ook aandacht besteed aan etnisch profileren, maar dit is niet het hoofdonderwerp van het onderzoek. 
van het politieoptreden. Gepercipieerde ongelijkheid of discriminatie is immers evenzo onwenselijk en schadelijk. Toch moet niet uit het oog worden verloren dat hiermee slechts een deel van de werkelijkheid aan het licht wordt gebracht. Hierdoor dreigt het gevaar dat in de algehele discussie over etnisch profileren voorbij wordt gegaan aan de complexiteit van het nemen van beslissingen en de veelheid aan factoren die daarbij een rol kunnen spelen.

Het moge duidelijk zijn dat het debat over risicoprofilering en de wenselijkheid maar ook de mogelijke negatieve effecten daarvan nog lang niet is uitgekristalliseerd. Terecht wijst Amnesty International ${ }^{11}$ dan ook op het belang van extra onderzoek naar het gebruik van risicoprofilering bij proactieve controles. Extra onderzoek is nodig om duidelijk inzicht te krijgen in de vraag welke factoren daadwerkelijk een rol spelen bij de beslissingen die door politieambtenaren en toezichthouders worden genomen bij dergelijke proactieve controles. In dit artikel wordt gepoogd hieraan een eerste bijdrage te leveren aan de hand van een uitgebreide (inter)nationale literatuurstudie naar risicoprofilering en het nemen van beslissingen binnen de opsporing en de handhaving. Hierbij staat de volgende onderzoeksvraag centraal: Welke factoren spelen een rol bij beslissingen die opsporingsambtenaren en toezichthouders (on)bewust nemen binnen hun discretionaire beoordelingsruimte? Het gaat hierbij om factoren op basis waarvan bewust dan wel onbewust wordt besloten dat een bepaalde situatie of een bepaalde persoon als mogelijk risicovol en daarmee misschien als potentieel verdacht kan worden aangemerkt.

\section{Methoden}

Hoewel vooralsnog weinig bekend is over de Nederlandse situatie, is er internationaal meer onderzoek gedaan. ${ }^{12}$ Het doel van dit artikel is om door middel van een studie van nationale maar vooral internationale literatuur een beeld te krijgen van indicatoren en factoren die mogelijk van belang zijn bij het vormen van profielen bij opsporingsambtenaren en toezichthouders en die dus mogelijk een rol spelen bij het nemen van discretionaire beslissingen. Omdat de studie in belangrijke mate een verkennend karakter heeft, is gekozen voor een vrij 'open' benadering. Er is bewust voor gekozen om zowel kwalitatieve als kwantitatieve

11 Amnesty International 2013.

12 J.A. Gilboy, 'Deciding who gets in: decision making by immigration inspectors', Law and Society Review 1991, p. 571-599; M.R. Smith \& M. Petrocelli, 'Racial profiling? A multivariate analysis of police traffic stop data', Police Quarterly 2001, 1, p. 4-27; G.P. Alpert, R.G. Dunham \& M.R. Smith, 'Investigating racial profiling by the Miami-Dade Police Department: A multimethod approach', Criminology \& Public Policy 2007, 1, p. 25-55; R.R. Johnson, The Development of Criminal Suspicion by State Troopers during Motor Vehicle Stops (diss. University of Cincinnati), 2007; K.S. Glover, M. Penalosa \& A. Schlarmann, 'Racial Profiling and Traffic Stops: An Examination of Research Approaches and Findings in the War on Drugs', Sociology Compass 2010, 4, p. 605-615; A. Pratt, 'Between a Hunch and a Hard Place: Making Suspicion Reasonable at the Canadian Border', Social \& Legal Studies 2010, 19, p. 461; R.R. Johnson \& M.A. Morgan, 'Suspicion Formation Among Police Officers: an international literature review', Criminal Justice Studies 2013, 1, p. 99-114. 
studies te verzamelen. Kwalitatief onderzoek geeft een beter inzicht in welke indicatoren de respondenten gebruiken tijdens hun werkzaamheden en in de achterliggende gedachten bij deze indicatoren. Kwantitatief onderzoek zal aan de andere kant meer cijfermatige aanwijzingen geven over welke mensen worden gestopt in het kader van proactieve controles.

De open benadering brengt eveneens met zich mee dat we niet van tevoren bepaald hebben hoeveel studiesin elk geval voor het onderzoek meegenomen zouden moeten worden. We hebben ons bij de literatuurstudie laten leiden door de inhoudelijke bevindingen, tot we op het moment kwamen dat sprake was van saturatie. Er werden geen nieuwe indicatoren meer gevonden, enkel een bevestiging van indicatoren die al gevonden waren. Dit betekent vanzelfsprekend dat we met dit onderzoek niet pretenderen een totaaloverzicht te bieden van alle literatuur op dit terrein. Echter, de beschreven resultaten zijn wel degelijk een reflectie van de algemeen gedeelde (inter)nationale bevindingen ten aanzien van de centraal staande thematiek.

Voor het verzamelen van de literatuur is gezocht in verschillende databases en zoekmachines: Web of Science, National Criminal Justice Reference Service, Picarta en Criminal Justice Abstracts. Aanvullend is gezocht via Google Scholar. Hierbij is gebruikgemaakt van de volgende zoektermen, hun Nederlandse equivalenten en combinaties van deze zoektermen: crime profiling, ethnic profiling, driving while Black, flying while Arab, profiling border control, actuarial methods profiling, smuggling profile, drug trade profile, drug courier profile, irregular immigration profiling, police suspicion, suspicious vehicles police, decision making, human trafficking, crime indicators, traffic stops, police discretion, cues for deception, non-verbal cues for deception. Bij deze zoektermen is gebruikgemaakt van enkele aanvullende, meer gedetailleerde zoekwoorden die zich richten op bijvoorbeeld landen of organisaties. Naast het zoeken via zoekmachines is tevens gezocht via de sneeuwbalmethode door de literatuurlijsten van de gevonden artikelen consequent te doorlopen op mogelijke relevante bijdragen. Naast wetenschappelijke artikelen is ook gezocht naar andere vormen van publicaties. In de scriptiebanken van de Nederlandse universiteiten is gezocht naar scripties die aansluiten bij dit onderwerp.

Binnen de via de hiervoor genoemde zoektermen gevonden artikelen vond vervolgens een selectie plaats op basis van titel en abstract. De uiteindelijk geselecteerde artikelen zijn niet allemaal volledig gericht op profielen en het gebruik daarvan. Ook artikelen die gedeeltelijk of kort ingaan op profileren of discretionaire bevoegdheden, maar die op basis van het abstract wel bruikbare informatie leken te bevatten, zijn meegenomen in de analyse. Tevens is niet alleen gebruikgemaakt van artikelen die ingaan op proactieve controles, maar zijn ook artikelen gebruikt die ingaan op de invulling van discretionaire bevoegdheden in bredere zin. Want hoewel de discussie in Nederland zich op het moment voornamelijk beperkt tot proactieve controles, zijn discretionaire bevoegdheden toepasbaar op een groter pallet aan taken. Het is daarom te verwachten dat ook hierover meer te vinden is in de literatuur.

De in de literatuur gevonden informatie is opgenomen in een bestand. Hieruit is een overzicht ontstaan van relevante indicatoren die binnen de verschillende studies een rol leken te spelen bij de verschillende typen (proactieve en niet-proac- 
tieve) controlebevoegdheden zoals toegepast door opsporingsambtenaren en toezichthouders. De resultaten uit de gevonden studies zijn tot slot geïnterpreteerd en geïntegreerd in een stuk, waardoor een categorisch overzicht is ontstaan van alle gevonden indicatoren.

\section{Resultaten}

In totaal zijn 49 wetenschappelijke artikelen gebruikt die iets zeggen over de indicatoren die worden gebruikt door opsporingsambtenaren en toezichthouders. Er zijn echter maar weinig studies die uitgebreid ingaan op deze indicatoren. Slechts tien artikelen gaan dieper op de stof in. In de overige 39 gevonden stukken wordt kort aandacht besteedt aan de indicatoren of worden ze enkel genoemd. Daarbij zijn drie scripties gevonden die ingaan op de vraag waarop de Nederlandse politie let bij de uitvoering van haar werk, en vijf boeken die op Nederland of de Verenigde Staten betrekking hebben.

Echte concrete risicoprofielen, dus vooraf vastgestelde profielen, worden weinig besproken in de literatuur. Alleen het in de Verenigde Staten gebruikte drug courier profile, suicide bomber profile en nanny profile zijn gevonden in de literatuur. ${ }^{13}$ Deze profielen zullen in het verloop van de resultaten worden besproken. Dat we weinig uitgewerkte profielen hebben gevonden, is geen verrassing. Zoals eerder aangegeven, zou het de veiligheid niet ten goede komen als de profielen openbare kennis zijn. Het wordt dan te gemakkelijk om aan de aandacht van toezichthouders en opsporingsambtenaren te ontgaan door simpelweg uiterlijk of gedrag aan te passen.

Uit de literatuur blijkt dat er een verdeling kan worden gemaakt in drie categorieën die van belang zijn bij het vormen van een beslissing om iemand te controleren of te stoppen. Ten eerste zijn er persoonskenmerken. Hieronder vallen demografische kenmerken zoals geslacht, leeftijd en huidskleur, maar ook uiterlijke kenmerken zoals kleding. De tweede categorie betreft de omstandigheden van de situatie en het gedrag. Hier wordt gekeken naar onder andere het gedrag ten opzichte van autoriteit en gedragingen tijdens controles, maar ook naar locaties en bestemmingen van reizigers. Situatie en gedrag zijn hier bij elkaar genomen omdat juist de combinatie van belang lijkt te zijn. Sommige gedragingen zouden in bepaalde situaties geen vragen oproepen, terwijl ze dat in een andere situatie wel doen. De derde en laatste categorie wordt gevormd door de kenmerken van het voertuig. Deze categorie is voornamelijk van toepassing bij controlebevoegdheden die worden toegepast in het verkeer. Er kan dan worden gedacht aan het

13 S.R. Chardak, 'Airport Drug Stops: Defining Reasonable Suspicion Based on the Characteristics of the Drug Courier Profile', Boston College Law Review 1984, 26, p. 693; Gilboy 1991; M.J. Kadish, 'Drug Courier Profile: In Planes, Trains, and Automobiles; And Now in the Jury Box', The American University Law Review 1996, 46, p. 747; Centre for Human Rights and Global Justice, Irreversible Consequences: Racial Profiling And Lethal Force In The 'War On Terror', New York: New York School of Law 2006; J. Pugliese, 'Biotypologies of Terrorism', Cultural Studies Review 2008, 2, p. 49-66. 
type, aanpassingen en de staat van het voertuig. In het navolgende zal worden beschreven wat over elk van deze drie factoren te vinden is in de literatuur.

\section{De persoon}

Uit de literatuur blijkt dat het uiterlijk van een persoon meerdere indicatoren kan bevatten die voor opsporingsambtenaren en toezichthouders interessant zijn. Het overgrote deel van de literatuur over welke personen de aandacht trekken, richt zich op etniciteit en huidskleur. Uit de meeste studies blijkt dat mensen met een donkere huidskleur eerder de aandacht trekken dan mensen met een andere huidskleur. ${ }^{14}$ Naast donkere mensen blijken ook mensen met een bepaald ander buitenlands voorkomen eerder op te vallen. Zo geven Nederlandse agenten aan dat ze letten op Marokkanen en Oost-Europeanen. ${ }^{15}$ Uit het Australisch onderzoek van Weber ${ }^{16}$ blijkt dat agenten bij het uitvoeren van immigratiecontroles in eerste instantie weinig andere indicatoren gebruiken dan huidskleur. Tóth en Kádár ${ }^{17}$ geven aan dat bij stop and search-controles in Hongarije blijkt dat Roma buitenproportioneel worden gestopt. Een interessant resultaat is te vinden in het onderzoek van Tillyer, Klahm en Engel. ${ }^{18}$ Hier werd gevonden dat alleen jonge donkere mensen meer werden gestopt dan andere groepen. Hierbij speelde huidskleur in combinatie met leeftijd een rol.

14 A.J. Meehan \& M.C. Ponder, 'Race and place: The ecology of racial profiling African American motorists', Justice Quarterly 2002, 3, p. 399-430; R.J. Lundman, 'Driver race, ethnicity, and gender and citizen reports of vehicle searches by police and vehicle search hits: Toward a triangulated scholarly understanding', Journal of Criminal Law and Criminology 2003, p. 94; R.J. Lundman \& R.L. Kaufman, 'Driving While Black: Effects Of Race, Ethnicity, And Gender On Citizen SelfReports Of Traffic Stops And Police Actions', Criminology 2003, 1, p. 195-220; R.G. Dunham e.a., 'Transforming citizens into suspects: Factors that influence the formation of police suspicion', Police Quarterly 2005, 3, p. 366-393; J.A. Schafer e.a., 'Decision making in traffic stop encounters: A multivariate analysis of police behavior', Police Quarterly 2006, 2, p. 184-209; M.R. Smith, M. Makarios \& G.P. Alpert, 'Differential suspicion: Theory specification and gender effects in the traffic stop context', Justice Quarterly 2006, 2, p. 271-295; Johnson 2007; M. Stroshine, G. Alpert \& R. Dunham, "The influence of "working rules" on police suspicion and discretionary decision making', Police Quarterly 2008, 3, p. 315-337; V. Borooah, 'Racial Disparity in Police Stop and Searches in England and Wales', Journal of Quantitative Criminology 2010, 4, p. 453-473; Glover, Penalosa \& Schlarmann 2010, p. 605-615; P. Quinton, 'The formation of suspicions: police stop and search practices in England and Wales', Policing and Society 2011, 4, p. 357-368; S. Wortley \& A. Owusu-Bempah, 'The usual suspects: police stop and search practices in Canada', Policing and Society 2011, 4, p. 395-407; Çankaya 2012.

15 S. Gunnink, 'Doelgroep? Dat zijn allochtonen.' Onderzoek naar interetnische relaties bij de politie Binnensticht (bachelorscriptie Universiteit Utrecht), 2010; C. Caillault, Ethnicity and policing in France and the Netherlands (masterthesis University of Amsterdam), 2011; M. Huijsen, Een verdacht profiel. Selectief politieoptreden in Veenendaal (bachelorscriptie Universiteit Utrecht), 2011; Çankaya 2012.

16 L. Weber, “It sounds like they shouldn't be here": immigration checks on the streets of Sydney', Policing and Society 2011, 4, p. 456-467.

17 B.M. Tóth \& A. Kádár, 'Ethnic profiling in ID checks by the Hungarian police', Policing and Society 2011, 4, p. 383-394.

18 R. Tillyer, C.F. Klahm \& R.S. Engel, 'The Discretion to Search A Multilevel Examination of Driver Demographics and Officer Characteristics', Journal of Contemporary Criminal Justice 2012, 2, p. 184-205. 
Maar er zijn ook onderzoeken die andere resultaten geven en kanttekeningen zetten bij de doorslaggevende rol die een buitenlands voorkomen zou spelen in het nemen van de beslissing om iemand te stoppen of aan een controle te onderwerpen. Zo geeft het onderzoek van Alpert, Dunham en Smith ${ }^{19}$ aan dat agenten maar in $30 \%$ van de gevallen de huidskleur van de bestuurder kon vaststellen voorafgaande aan de stop. Daarbij blijkt uit de onderzoeksresultaten dat donkere mensen niet buitenproportioneel worden gestopt. Wel zijn er verschillen te vinden in de resultaten van de stop. Hoewel mensen met een donkere huidskleur niet buitenproportioneel worden gestopt, blijkt dat hun auto's wel vaker worden doorzocht naar aanleiding van de stop. Ditzelfde blijkt ook uit het rapport van Verniero en Zoubek ${ }^{20}$ en de onderzoeken van Engel en Calnon, ${ }^{21}$ Gaines ${ }^{22}$ en Ridgeway. ${ }^{23}$ Uit het onderzoek van Lundman en Kaufman ${ }^{24}$ blijkt voorts dat LatijnsAmerikaanse bestuurders minder worden gestopt dan blanke bestuurders. In de interviews die Johnson ${ }^{25}$ heeft gehouden met agenten, geven enkele respondenten aan dat etniciteit geen goede voorspeller is, aangezien criminaliteit onder alle etniciteiten voorkomt.

In enkele onderzoeken wordt gesproken over de combinatie van een buitenlands voorkomen en omgeving. ${ }^{26}$ Wanneer mensen met een bepaald voorkomen zich bevinden in een omgeving waar het niet heel gebruikelijk is dat mensen met een dergelijk uiterlijk er komen, trekt dat de aandacht. Hiervoor wordt ook wel de uitdrukking 'white boy in a no white boy zone' gebruikt, ${ }^{27}$ doelende op een blanke persoon uit de middenklasse die zich bevindt in een arme, criminaliteitsrijke, voornamelijk donkere buurt. De aanname die wordt gedaan, is dat deze persoon daar niet thuishoort en daar waarschijnlijk is voor drugs of een prostituee. Het omgekeerde kan ook voorkomen: donkere mensen in een oude, beschadigde auto die rondrijden in een rijke, voornamelijk blanke buurt. Ook hierbij wordt verondersteld dat deze personen niet thuishoren in die buurt, wat vragen oplevert.

Nationaliteit blijkt eveneens voor de nodige verdenkingen te kunnen zorgen. In het onderzoek van Pratt en Thompson ${ }^{28}$ naar grensbewaking in Canada wordt dit door een respondent mooi beschreven met de uitspraak 'some passports are bet-

19 Alpert e.a. 2007.

20 P. Verniero \& P.H. Zoubek, Interim report of the state police review team regarding allegations of racial profiling, New Jersey, NJ: New Jersey Department of Law and Public Safety 1999.

21 R.S. Engel \& J.M. Calnon, 'Examining the influence of drivers' characteristics during traffic stops with police: Results from a national survey', Justice Quarterly 2004, 1, p. 49-90.

22 L.K. Gaines, 'An analysis of traffic stop data in Riverside, California', Police Quarterly 2006, 2, p. 210-233.

23 G. Ridgeway, 'Assessing the effect of race bias in post-traffic stop outcomes using propensity scores', Journal of Quantitative Criminology 2006, 1, p. 1-29.

24 Lundman \& Kaufman 2003.

25 Johnson 2007.

26 L. Holmberg, 'Discretionary leniency and typological guilt: Results from a Danish study of police discretion', Journal of Scandinavian studies in criminology and crime prevention 2000, 2, p. 179-194; Dunham e.a. 2005; Glover, Penalosa \& Schlarmann 2010; Johnson 2007.

27 K.S. Glover, 'Police discourse on racial profiling', Journal of Contemporary Criminal Justice 2007, 3, p. 239-247.

28 A. Pratt \& S.K. Thompson, 'Chivalry, "race" and discretion at the Canadian border', British journal of criminology 2008, 5, p. 620-640. 
ter than others'. Sommige nationaliteiten worden in verband gebracht met bepaalde vormen van criminaliteit. Als voorbeelden worden drugshandel vanuit Jamaica en Zuid-Amerika, witwassen vanuit Aziatische landen en illegale arbeid vanuit Oost-Europa genoemd. ${ }^{29}$ In Nederland worden Oost-Europeanen ook gezien als een risicogroep. ${ }^{30}$ Daartegenover staat dat sommige nationaliteiten ook als positief worden gezien. ${ }^{31}$ Reizigers uit bepaalde landen worden minder streng gecontroleerd omdat de ervaring leert dat zij een laag risico vormen. In de studie worden deze landen niet bij naam genoemd.

Huidskleur, een buitenlands voorkomen en nationaliteit worden overduidelijk het vaakst genoemd in de literatuur als persoonsgerelateerde factoren die mogelijk van invloed zijn op het nemen van discretionaire beslissingen. Desondanks zijn er wel degelijk nog andere factoren die eveneens een belangrijke rol kunnen spelen. Dit zijn geslacht, leeftijd, kleding en eerder contact met de autoriteiten.

Ten aanzien van het geslacht wijst de literatuur duidelijk één kant op: mannen worden eerder geassocieerd met criminaliteit dan vrouwen. ${ }^{32}$ Ook leeftijd lijkt een uitgemaakte zaak: jongeren worden sneller aangeduid als een verdachte persoon. ${ }^{33}$ Een interessante opmerking wordt gemaakt in het onderzoek van Johnson. ${ }^{34}$ Hierin wordt in de interviews aangegeven dat bij leeftijd wel een kanttekening gezet kan worden. Agenten vertellen dat, wanneer het om drugs gaat, bij jongeren vaak minder grote hoeveelheden worden gevonden dan bij volwassenen. Kleding kan eveneens een rol spelen. Met name sport- en hiphopkleding worden genoemd in meerdere onderzoeken. ${ }^{35}$ Trainingspakken, petjes, bontkragen en truien met capuchons worden gezien als een negatieve indicatie. De achterliggende gedachte is onder andere dat men zich kan verbergen achter een pet of capuchon. Ook volledig zwarte kleding wordt gezien als een teken dat iemand kwade plannen heeft. ${ }^{36}$ In het onderzoek van Çankaya ${ }^{37}$ worden tevens enkele specifieke kledingmerken genoemd die men associeert met criminele betrokkenheid: Nike, Cavalli, Armani, Prada, Gucci, Moncler, Dsquared en Woolrich. Dure sieraden vallen ook op. Als deze worden gedragen door een persoon die er verder

29 Gilboy 1991; S.R. Gross \& K.Y. Barnes, 'Road work: Racial profiling and drug interdiction on the highway', Michigan Law Review 2002, 3, p. 651-754; Pratt \& Thompson, 2008; Pratt, 2010; A. Unlu \& B. Ekici, 'The extent to which demographic characteristics determine international drug couriers' profiles: a cross-sectional study in Istanbul', Trends in Organized Crime 2012, 4, p. 296-312.

30 Çankaya 2012.

31 Gilboy 1991.

32 Lundman 2003, p. 309; Lundman \& Kaufman 2003; Schafer e.a. 2006; Smith, Makarios \& Alpert 2006, p. 271-295; Alpert e.a., 2007; D.K. Rossmo e.a., 'Geographic patterns and profiling of illegal crossings of the southern US border', Security Journal 2008, 1, p. 29-57; Holmberg 2000; Çankaya 2012; W. Regoeczi \& S. Kent, Examining The Application Of Discretion In Police DecisionMaking In Cuyahoga County 2012; Tillyer, Klahm \& Engel 2012.

33 Quinton 2011; Çankaya 2012; Tillyer, Klahm \& Engel 2012.

34 Johnson 2007.

35 G.J. Smith, 'Behind the screens: Examining constructions of deviance and informal practices among CCTV control room operators in the UK', Surveillance \& Society 2002, 2/3; Quinton 2011; Çankaya 2012.

36 Dunham e.a. 2005.

37 Çankaya 2012. 
niet welvarend uitziet, wordt de aanname gemaakt dat de sieraden niet op legale wijze zijn verkregen of verdiend. ${ }^{38}$ De International Association of Police Chiefs geeft in haar Training Key 581 aan dat dikke kleding in de zomer of overmatig grote kleding een teken kan zijn dat men iets onder de kleding verbergt waarmee een zelfmoordaanslag kan worden gepleegd. ${ }^{39}$ In diezelfde Training Key worden enkele andere indicatoren genoemd die mogelijk duiden op terrorisme. ${ }^{40} \mathrm{Zo}$ worden slecht gekleurd haar, overmatig gebruik van parfum of eau de cologne en het gebruik van talkpoeder genoemd. Daarnaast geeft de Transportation Security Administration ${ }^{41}$ aan dat chemische brandwonden van bijvoorbeeld bleek of zuur op de handen reden kunnen zijn voor verder onderzoek. Dit kan namelijk een teken zijn dat iemand met chemicaliën heeft gewerkt, bijvoorbeeld om explosieven te maken.

Mensen die eerder in aanraking zijn gekomen met de autoriteiten, hebben een grotere kans om aan de kant te worden gezet. ${ }^{42}$ Agenten zijn bekend met de mensen in het gebied waar de politie regelmatig patrouilleert en anderszins actief is. $\mathrm{Zij}$ weten daarom wie eerder in contact is geweest met justitie en letten extra op deze mensen. ${ }^{43}$ Uit het onderzoek van Quinton ${ }^{44}$ blijkt dat bij deze personen ook minder indicatoren aanwezig hoeven te zijn dan bij mensen die niet bekend zijn bij de politie.

\section{Het gedrag en de omstandigheden}

Het gedrag van mensen kan ook een indicator zijn. ${ }^{45}$ In het onderzoek van Çankaya ${ }^{46}$ wordt genoemd dat mensen die doelloos rondlopen of rondhangen in de gaten worden gehouden. Het ontwijken van contact met de politie wordt in meerdere stukken genoemd. ${ }^{47}$ Mensen die plots omdraaien wanneer zij agenten zien, roepen vragen op. ${ }^{48}$ Dat geldt niet alleen voor personen, maar ook voor voertuigen. ${ }^{49}$ Auto's die zich weg bewegen van de patrouillewagen of groepen die zich opsplitsen, worden in de gaten gehouden. Ook het vermijden van oogcontact tijdens het rijden wordt gezien als een indicator dat er iets niet pluis is. ${ }^{50}$ Dit laatste wordt ook wel de felony stare genoemd: het zenuwachtig voor zich uitkijken wan-

Çankaya 2012.

Centre for Human Rights and Global Justice 2006; Pugliese 2008.

Centre for Human Rights and Global Justice 2006; Pugliese 2008.

Transportation Security Administration, TSA Possible Suicide Bomber Indicators, 2008.

G.F. Vito \& W.F. Walsh, 'Suspicion and traffic stops: crime control or racial profiling', International Journal of Police Science and Management 2008, 1, p. 89-100; Stroshine, Alpert \& Dunham 2008, p. 315-337; Quinton 2011; Çankaya 2012.

Dunham e.a. 2005; Holmberg 2000.

Quinton 2011.

Dunham e.a. 2005; Regoeczi \& Kent 2012.

Çankaya 2012.

J. Rubinstein, City police, New York: Macmillan 1980; Dunham e.a. 2005; Johnson 2007; Quinton 2011; Çankaya 2012; Johnson \& Morgan 2013.

Çankaya 2012.

Johnson 2007.

Rubenstein 1980; Centre for Human Rights and Global Justice 2006; Johnson 2007. 
neer een agent in de buurt komt. Zenuwachtig gedrag in het algemeen wordt door agenten als verdacht beschouwd. ${ }^{51}$

Gerelateerd aan het ontwijken van contact met de politie is het erg nauwkeurig volgen van de verkeersregels. Agenten geven aan niet alleen te letten op mensen die opvallen door regels te overtreden, maar ook op mensen die zich heel erg netjes aan de regels houden. ${ }^{52}$ Dit zou een teken zijn dat men contact met de politie wil vermijden, mogelijk omdat men iets te verbergen heeft. Ook langzaam rijden of sterk afremmen wanneer een patrouilleauto in de buurt komt, wordt gezien als verdacht.

Naast het gedrag op de weg kan het gedrag tijdens een gesprek met een opsporingsambtenaar of toezichthouder aanleiding zijn om verder te vragen. Hier wordt, net als bij het rijden, de ontwijkende blik genoemd. ${ }^{53}$ Agenten geven aan dat wanneer mensen in een gesprek oogcontact vermijden, dit wordt gezien als een teken dat ze wat te verbergen hebben. Hetzelfde kan gezegd worden over het excessief bewegen van ledematen tijdens het gesprek, het tonen van valse emoties en overmatig glimlachen. ${ }^{54}$ Deze onderzoeken tonen aan dat er ook verbale aanwijzingen zijn die opsporingsambtenaren en toezichthouders alert maken. Met name stotteren, lange pauzes in zinnen en spraakonderbrekingen worden gezien als aandachtspunt.

Niet alleen het gedrag tijdens het gesprek, maar ook de inhoud is belangrijk. In het onderzoek van Gilboy ${ }^{55}$ bij de Canadese grensbewaking geven de respondenten aan dat mensen die niet kunnen zeggen waar ze heengaan, onmiddellijk als kwestieus worden beschouwd. Dit wordt eveneens genoemd door de agenten in het onderzoek van Johnson. ${ }^{56}$ Wanneer mensen wel een bestemming kunnen noemen, maar dit niet wordt ondersteund door de rest van de situatie, levert dat vragen op. ${ }^{57}$ Voorbeelden zijn mensen die zeggen op vakantie te gaan maar geen bagage bij zich hebben, mensen met veel bagage of lege koffers die ergens op bezoek gaan, of mensen die onredelijk ver reizen voor een triviaal doel, zoals een kapper. Bepaalde bestemmingen of doelen vereisen tevens extra aandacht. Gilboy ${ }^{58}$ noemt als specifiek voorbeeld het 'nanny'-scenario. Jonge vrouwen die ver reizen, bijvoorbeeld vanuit Oost-Europa naar de Verenigde Staten, om ergens als

51 Chardak 1984; Johnson 2007; Pratt 2010.

52 H. Sacks, 'Notes on police assessment of moral character', Studies in social interaction, 1972, p. 280-293; Johnson 2007.

53 L. Akehurst e.a., 'Lay persons' and police officers' beliefs regarding deceptive behavior', Applied Cognitive Psychology 1996, 6, p. 461-471; A. Vrij \& G.R. Semin, 'Lie experts' beliefs about nonverbal indicators of deception', Journal of nonverbal behavior 1996, 1, p. 65-80; A. Vrij \& S. Mann, 'Who killed my relative? Police officers' ability to detect real-life high-stake lies', Psychology, Crime and Law 2001, 1-4, p. 119-132; L. Strömwall \& P.A. Granhag, 'How to detect deception? Arresting the beliefs of police officers, prosecutors and judges', Psychology, Crime and Law 2003, 1, p. 19-36; S. Mann, A, Vrij \& R. Bull, 'Detecting true lies: police officers' ability to detect suspects' lies', Journal of applied psychology 2004, 1, p. 137; Johnson 2007.

54 Akehurst e.a. 1996; Vrij \& Semin 1996; Vrij \& Mann 2001; Strömwall \& Granhag 2003.

55 Gilboy 1991.

56 Johnson 2007.

57 Chardak 1984; Johnson 2007.

58 Gilboy 1991. 
nanny te gaan werken, worden langer ondervraagd. Met name wanneer blijkt dat zij niets afweten van hun bestemming of het gezin waar ze gaan werken, is de verdenking van illegale immigratie snel gemaakt. De mate van detail in een verhaal is ook een factor. In het onderzoek van Strömwall en Granhag ${ }^{59}$ geven respondenten aan dat mensen die veel details kunnen vertellen, minder snel verdacht zijn. De verhalen moeten daarbij wel consistent blijven en geen leugens bevatten. ${ }^{60}$

De Amerikaanse Drugs Enforcement Administration (DEA) heeft enkele specifieke factoren opgenomen in het drug courier profile. ${ }^{61}$ Dit profiel is voornamelijk van toepassing op luchthavens. Het profiel is echter niet hetzelfde in de gehele Verenigde Staten en kan per district verschillen. Er kan worden gelet op vluchten naar en van locaties die gekoppeld worden aan drugssmokkel. Met name wanneer een persoon een verre reis maakt naar een dergelijke locatie en snel weer vertrekt of heel vaak naar deze locaties reist, gaan er belletjes rinkelen. Personen die veel geld bij zich hebben of hun ticket betalen in veel kleine coupures, staan ook onder de aandacht. Verder wordt gelet op enkele gedetailleerde gedragingen. Bellen meteen na de landing, een niet-werkend telefoonnummer opgeven bij de luchtvaartmaatschappij en gebruikmaken van een alias zijn factoren die in het drug courier profile kunnen worden opgenomen.

De Training Key 581 van de International Association of Police Chiefs geeft enkele kenmerken van gedrag die mogelijk duiden op terrorisme of zelfmoordaanslagen. ${ }^{62}$ Rondrijden of heen en weer lopen bij een locatie wordt beschouwd als een indicator. Daarnaast worden meer gedetailleerdere gedragingen genoemd: om zich heen kijken en langzaam lopen, recht voor zich uitkijkend op een doel aflopen, handelingen onder kleding, overbeschermend zijn wat betreft de bagage, en vaak controleren van de tijd of telefoon. Ook angstig en zenuwachtig gedrag wordt in de lijst genoemd. De Amerikaanse Transportation Security Administration heeft enkele toevoegingen op dit suicide bomber profile. ${ }^{63} \mathrm{Zij}$ noemt als aanvullende indicatoren: op een onnatuurlijke manier lopen, eigen kleding aftasten en kijken alsof men zich in een trance bevindt.

\section{Het voertuig}

Uit de literatuur blijkt dat het voertuig ook van belang kan zijn bij de beslissingen van opsporingsambtenaren en toezichthouders. Er worden enkele specifieke indicatoren ten aanzien van het voertuig genoemd die een rol kunnen spelen bij de beslissing iemand wel of niet te stoppen. Opvallende aanpassingen aan auto's trekken de aandacht van toezichthouders, zo blijkt uit meerdere onderzoeken. Zo worden in de studies van Johnson ${ }^{64}$ en Dunham en anderen ${ }^{65}$ grote velgen, grote spoilers, verlaagde veringen en opvallend spuitwerk genoemd. Dit sluit aan bij 
wat de Nederlandse politie 'patserbakken' noemt. ${ }^{66}$ De meeste aandacht lijkt echter uit te gaan naar getinte ruiten. Dit zou een teken zijn dat de bestuurder wat te verbergen heeft.

Aanpassingen aan het plaatwerk van de auto kunnen ook een indicatie zijn voor criminele betrokkenheid. Wanneer er tekens zijn dat in het plaatwerk is gesneden, zou dat kunnen duiden op verborgen compartimenten voor het smokkelen van bijvoorbeeld drugs. ${ }^{67}$ Hetzelfde geldt voor asymmetrisch plaatwerk, doorhangende veringen of onderdelen die onder de auto hangen. Het verbergen van schade aan de auto levert eveneens verdenking op. In het onderzoek van Cherbonneau en Copes $^{68}$ geven dieven als voorbeeld aan dat ze schade aan de stuurkolom proberen te verbergen door er een shawl of doek omheen te wikkelen. Deze poging om schade te verbergen trekt juist extra aandacht naar de auto, omdat het niet in het normale beeld van een auto past.

De kwestie van het type auto levert in de literatuur verschillende resultaten op. In de gesprekken die in het artikel van Johnson ${ }^{69}$ worden beschreven, geven agenten verschillende antwoorden op de vraag of het type voertuig een indicator kan zijn. Sommige agenten letten wel op bepaalde typen auto's, terwijl anderen aangeven dat het selecteren op type nutteloos is. Engel en Johnson ${ }^{70}$ geven in hun studie aan dat grotere voertuigen en SUV's meer ruimte hebben voor bagage en comfortabeler zijn voor langere afstanden. Ze zouden daarom de voorkeur krijgen van drugskoeriers. In het onderzoek van Çankaya ${ }^{71}$ geven Nederlandse agenten aan extra op bepaalde typen en merken van auto's te letten. Audi, BMW, Mercedes en Hummer worden genoemd als aandachtstrekkers. Een belangrijk punt dat hierbij genoemd wordt, is dat de persoon in de auto moet kloppen bij het voertuig. Een jonge persoon in een dure auto zou aanleiding geven tot meer onderzoek. De reden die hieraan ten grondslag ligt, is dat jongeren over het algemeen niet in staat zouden zijn dergelijke dure auto's op legale wijze te verkrijgen. ${ }^{72}$

De leeftijd van de auto lijkt voor sommige agenten ook een indicator te zijn. Zowel in het onderzoek van Johnson ${ }^{73}$ als dat van Tillyer, Klahm en Engel ${ }^{74}$ en Çankaya ${ }^{75}$ geven agenten aan dat oude, slecht onderhouden auto's hun aandacht trekken. Uit het onderzoek van Alpert, Dunham en Smith ${ }^{76}$ bleek echter dat oudere auto's niet vaker aan de kant worden gezet. Wel worden gebreken aan de

66 Çankaya 2012.

67 E.F. Connors \& H. Nugent, Street-level narcotics enforcement, US Department of Justice, Office of Justice Programs, Bureau of Justice Assistance 1990; Johnson 2007.

68 M. Cherbonneau \& H. Copes, “Drive it like you Stole it”. Auto Theft and the Illusion of Normalcy', British Journal of Criminology 2006, 2, p. 193-211.

69 Johnson 2007.

70 R.S. Engel \& R. Johnson, 'Toward a better understanding of racial and ethnic disparities in search and seizure rates', Journal of Criminal Justice 2006, 6, p. 605-617.

71 Çankaya 2012.

72 Gunnink 2010; Çankaya 2012; Johnson \& Morgan 2013.

73 Johnson 2007.

74 Tillyer, Klahm \& Engel 2012.

75 Çankaya 2012.

76 Alpert e.a. 2007. 
auto soms gebruikt als reden om een auto aan de kant te zetten om vanuit daar ook op andere punten te letten. ${ }^{77}$

Speciale aandacht gaat uit naar huurauto's, zo blijkt uit meerdere onderzoeken. ${ }^{78}$ Criminelen zouden er rekening mee houden dat hun auto in beslag kan worden genomen. Daarom maken ze liever gebruik van een huurauto dan van hun eigen auto. Enkele factoren dragen eraan bij om een huurauto extra te laten opvallen. Ten eerste is er de origine van de auto. ${ }^{79}$ Huurauto's waarmee lange afstanden zijn afgelegd, zouden kunnen wijzen op smokkel. Daarnaast zijn persoonlijke items, zoals stickers en hangers aan de binnenspiegel, in een huurauto reden voor aandacht. ${ }^{80}$ Dit kan erop wijzen dat de auto al langere tijd in gebruik is bij dezelfde persoon, wat niet gebruikelijk is voor een huurauto.

De kentekenplaat kan ook van belang zijn als indicator. ${ }^{81}$ Toezichthouders kunnen letten op kentekenplaten uit gebieden die bekendstaan om bepaalde vormen van criminaliteit. Hierbij wordt met name drugssmokkel genoemd. In Nederland gebruiken politieagenten de kentekenplaat tevens om de bestuurder na te trekken. ${ }^{82}$ Wanneer de persoonsinformatie gekoppeld aan het kenteken niet overeenkomt met de bestuurder op dat moment, kan dat reden zijn voor een controle. ${ }^{83}$ Ook wordt in het onderzoek van Çankaya ${ }^{84}$ genoemd dat buitenlandse kentekens meer aandacht krijgen dan Nederlandse kentekens. Daarnaast zijn er enkele fysieke eigenschappen van de kentekenplaat waarop men kan letten. Zo zou een schone kentekenplaat op een vies voertuig of een kentekenplaat met insecten erop aan de achterkant van het voertuig erop kunnen duiden dat de kentekenplaat onlangs is verwisseld. Tijdelijke kentekenplaten en platen die niet goed vastzitten roepen eveneens vragen op. ${ }^{85}$

Naast voornoemde factoren lijken agenten ook op kleinere details te letten. Zo zouden zogenoemde disclaimers aandacht trekken. ${ }^{86}$ Met disclaimers wordt bedoeld dat de inzittenden met behulp van bijvoorbeeld bumperstickers het idee willen opwekken dat van hen niets te vrezen is. Hierbij kan worden gedacht aan stickers die aangeven dat iemand voorstander is van de politie of een oud-soldaat is. Deze disclaimers kunnen door de agenten worden gezien als een manier om de aandacht af te leiden van wat er daadwerkelijk gaande is in het voertuig. Het tegenovergestelde van disclaimers bestaat ook: afbeeldingen die worden gekoppeld aan criminaliteit. In het stuk van Thornton ${ }^{87}$ wordt genoemd dat afbeeldingen

78 Connors \& Nugent 1990; Gross \& Barnes 2002; Johnson 2007; B.H. Thornton, 'Soccer Mom or Drug Trafficker: Why the Consideration of Religious Symbols in an Officer's Reasonable Suspicion Calculus Does Not Offend the First Amendment', Texas Tech Law Review 2009, 42, p. 123; Çankaya 2012; Johnson \& Morgan 2013.

80 Johnson \& Morgan 2013.

81 Johnson 2007; Çankaya 2012.

82 Çankaya 2012.

83 Connors \& Nugent 1990; Çankaya 2012.

84 Çankaya 2012.

85 Rubinstein 1980; Connors \& Nugent 1990.

86 Johnson 2007.

87 Thornton 2009. 
van de beschermheilige Jesus Malverde worden geassocieerd met drugshandel en dat voertuigen met deze afbeelding in de gaten worden gehouden.

Voorwerpen in de auto kunnen eveneens een aanwijzing zijn. Bijvoorbeeld een overdaad aan luchtverfrissers, ook wel een felony forest genoemd. ${ }^{88}$ Deze kunnen worden gebruikt om de geur van bijvoorbeeld drugs te verbloemen. Verder wordt gelet op hulpmiddelen voor het gebruiken van drugs, zoals naalden, weegschaaltjes of buisjes. ${ }^{89}$ Een rommelig interieur met veel afval in het voertuig kan ook een indicator zijn. ${ }^{90}$ In enkele onderzoeken worden mobiele telefoons genoemd. ${ }^{91}$ Bij met name drugssmokkel zou men gebruikmaken van meerdere telefoons of simkaarten, zodat men persoonlijke en zakelijke communicatie kan scheiden. De aanwezigheid van meerdere telefoontoestellen in een auto kan daarom als indicator worden gezien.

\section{Discussie}

Zoals in paragraaf 1 is aangeduid, richt de discussie rondom profileren zich op het moment voornamelijk op het element etniciteit. Uit de gevonden literatuur blijkt dat dit ook op internationaal vlak het geval is. Wanneer wordt gezocht naar literatuur over profileren, stuit men grotendeels op stukken over etnisch profileren. Met name in de Amerikaanse literatuur is veel geschreven over dit onderwerp. De insteek van deze literatuur is meestal juridisch. Hierbij worden de juridische kaders uitgebreid besproken en soms gekoppeld aan traffic stop-data die op verschillende plekken zijn verzameld. De onderzoeken die zich richten op traffic stops gaan echter niet diep in op het beslissingsproces. Ze kijken voornamelijk naar wie er wordt gestopt en wat de uitkomst is, maar gaan niet in op de achterliggende gedachte van de stop. Daarnaast zijn er ook opmerkingen te maken bij de betrouwbaarheid van de traffic stop-data. Zoals Gross en Barnes ${ }^{92}$ opmerken, worden niet al deze data op vrijwillige basis verzameld door de politie. Aangezien de informatie tegen hen gebruikt kan worden, is het niet ondenkbaar dat met de informatie wordt gerommeld. Dat dit niet onrealistisch is, blijkt ook uit het feit dat agenten daadwerkelijk zijn betrapt op het frauderen met de gegevens.

Tegenover de grote hoeveelheid juridische teksten en beperkte empirische onderzoeken staan maar weinig onderzoeken naar hoe opsporingsambtenaren hun discretionaire bevoegdheden invullen. De onderzoeken die dieper op deze stof ingaan, ${ }^{93}$ geven aan dat er achter de beslissingen die genomen worden een complex proces zit. Er zijn veel factoren die kunnen bijdragen aan het nemen van beslissingen. Hoe deze factoren meewegen in de beslissing, verschilt ook per situatie, wat het geheel nog complexer maakt. In meerdere stukken wordt genoemd dat sprake is van een gut feeling, instinct, dingen die niet in het plaatje passen of

88 Connors \& Nugent 1990; Johnson 2007.

89 Connors \& Nugent 1990.

90 Connors \& Nugent 1990; Johnson 2007.

91 Thornton 2009; Unlu \& Ekici 2012.

92 Gross \& Barnes 2002.

93 Holmberg 2000; Alpert e.a. 2007; Johnson 2007; Quinton 2011; Çankaya 2012. 
andere contextuele factoren die door de agenten moeilijk uit te leggen zijn. ${ }^{94}$ Er lijkt dus sprake te zijn van een professionele intuïtie, die men door middel van ervaring verkrijgt. Daarnaast wordt in deze stukken genoemd dat het niet gaat om een specifieke factor. Het blijkt de combinatie van verschillende factoren te zijn die zorgt dat agenten actie ondernemen.

Opvallend is ook dat de term 'etnisch profileren' in de literatuur op verschillende manieren wordt gebruikt. De een verstaat onder etnisch profileren het selecteren puur op basis van etniciteit. Situationele factoren worden hierbij buiten beschouwing gelaten. Anderen verstaan onder etnisch profileren het gebruiken van etniciteit als een van de factoren die bijdragen aan de selectieprocedure. Hierbij worden situationele factoren wel meegenomen in de beslissing. MacDonald ${ }^{95}$ noemt dit respectievelijk 'hard' en 'zacht' profileren. Tegenstanders van etnisch profileren maken vaak gebruik van de tweede variant. Zij willen dat etniciteit volledig buiten beschouwing wordt gelaten. Voorstanders van profileren zijn vaak minder streng en vinden dat etniciteit onderdeel mag zijn van de beslissing. Zij gebruiken de term etnisch profileren dan ook wanneer er alléén naar etniciteit wordt gekeken. Barlow en Barlow ${ }^{96}$ merken hierbij op dat wanneer men de term invult als hard profileren, het afkeuren en ontkennen van etnisch profileren wel gemakkelijk wordt gemaakt. Het is namelijk al snel aan te tonen dat meer dan alleen etniciteit heeft bijgedragen aan de genomen beslissing.

Behalve dat op de term etnisch profileren als geheel commentaar kan worden geleverd, kan dat ook op het gebruik van het woord 'etnisch'. Het Nationaal Kompas Volksgezondheid hanteert de volgende definitie van etniciteit: 'Etniciteit is een verzameling van culturele kenmerken en gedragingen die door een groep mensen worden gedeeld en van generatie op generatie overgedragen worden. Leden van etnische groepen identificeren zich met gezamenlijke factoren, zoals herkomst, uiterlijke kenmerken, religie, taal, cultuur of geschiedenis. ${ }^{97}$

De definitie van etniciteit blijkt erg breed te zijn. Toch wordt de term in de huidige discussie voornamelijk gebruikt als synoniem voor uiterlijke kenmerken en mogelijke geloofsovertuigingen die hieruit kunnen worden afgeleid. Hierbij wordt voorbijgegaan aan de vele andere componenten die etniciteit kan bevatten. Dit maakt de discussie niet gemakkelijker, aangezien het niet duidelijk is of iedereen het over hetzelfde heeft.

Opvallend is ook dat een andere normaal veelbesproken factor in het profileringsdebat niet wordt genoemd: gender. Er wordt veel afkeurend geschreven over uiterlijke kenmerken als factor in de genomen beslissing, maar gender wordt hierbij niet meegenomen. Dit terwijl de gevonden literatuur erg duidelijk is over wat de rol hiervan is. Mannen worden eerder geassocieerd met criminaliteit dan vrou-

94 Holmberg 2000; H.M. Lomell, 'Targeting the unwanted: Video surveillance and categorical exclusion in Oslo, Norway', Surveillance \& Society 2002, 2/3; Dunham e.a. 2005; Glover 2007; Johnson 2007; Pratt 2010.

95 H. MacDonald, 'The myth of racial profiling', City Journal 2001, 2, p. 14-27.

96 D.E. Barlow \& M.H. Barlow, 'Racial profiling: A survey of African American police officers', Police Quarterly 2002, 3, p. 334-358.

97 Nationaal Kompas Volksgezondheid, Etniciteit: definitie en gegevens, 2013. Bezocht op 14 november 2013 via www.nationaalkompas.nl/bevolking/etniciteit/wat-is-etniciteit/. 
wen. ${ }^{98}$ Mogelijk komt dit doordat algemeen wordt aangenomen dat mannen meer criminaliteit plegen dan vrouwen. Maar uit het onderzoek van Johnson ${ }^{99}$ blijkt dat hier ook anders naar gekeken kan worden. Agenten geven aan dat ze bij controles van vrouwen terughoudender zijn met fouilleren wanneer zij niet genoeg bewijs hebben voor een arrestatie. Dergelijke praktijken zouden eveneens voor discussie kunnen zorgen, maar worden op het moment niet in het profileringsdebat genoemd.

Naast deze meer theoretische problemen zijn er ook praktische problemen met profileren. Het principe van actie-reactie is ook van toepassing op criminaliteit. Wanneer veiligheidsfunctionarissen zich concentreren op een bepaald profiel of persoonskenmerk, zal dat gaan opvallen bij de personen die in het profiel passen. Als gevolg zullen zij zich op een andere manier gaan kleden of gedragen, zodat zij buiten het profiel vallen. Zo wordt in het stuk van Ruiz en Woessner ${ }^{100}$ genoemd dat de agenten in het onderzochte district veel letten op huurauto's, omdat uit ervaring zou zijn gebleken dat criminelen hier veel gebruik van maken. Gedurende het onderzoek levert echter geen enkele stop van een huurauto een arrestatie op. Dit zou een voorbeeld kunnen zijn van criminelen die hun modus operandi aanpassen, zodat ze geen aandacht van de politie trekken. Unlu en Ekici ${ }^{101}$ zien in hun onderzoek dat bij drugssmokkel via luchthavens steeds meer gebruik wordt gemaakt van mensen die buiten profielen vallen. Zo worden kinderen, ouderen en zwangere vrouwen ingezet om aan toezicht te ontkomen. Vrouwen in het algemeen lijken steeds meer vertegenwoordigd te worden in de cijfers van drugssmokkel.

Vanuit de wetenschap komt ook kritiek op sommige methoden die worden gebruikt bij het selecteren van verdachte personen. Een goed voorbeeld zijn de gedragsindicatoren die worden gebruikt om tijdens een gesprek te achterhalen of iemand de waarheid vertelt of niet. Uit meerdere onderzoeken blijkt dat agenten niet beter zijn in het herkennen van leugens dan studenten. ${ }^{102}$ Agenten blijken gebruik te maken van indicatoren waarvan uit onderzoek is gebleken dat ze geen leugenachtig gedrag aanduiden. Een oorzaak hiervan zou kunnen zijn dat veel van deze onjuiste indicatoren in een prominent boek worden gepresenteerd als juist. ${ }^{103}$ Uit het onderzoek van O'Sullivan en anderen ${ }^{104}$ komt een kanttekening naar voren die hierbij gemaakt moet worden. Zij geven aan dat de eerder uitgevoerde onderzoeken niet de juiste scenario's gebruiken. In hun onderzoek scoren

98 Lundman 2003; Lundman \& Kaufman 2003; Schafer e.a. 2006; Smith e.a. 2006; Alpert e.a. 2007; Rossmo e.a. 2008; Holmberg 2010; Çankaya 2012; Regoeczi \& Kent 2012; Tillyer, Klahm \& Engel 2012.

99 Johnson 2007.

100 J. Ruiz \& M. Woessner, 'Profiling, Cajun style: racial and demographic profiling in Louisiana's war on drugs', International Journal of Police Science \& Management 2006, 3, p. 176-197.

101 Unlu \& Ekici 2012.

102 Vrij \& Semin 1996; Vrij, Edward \& Bull 2001; Strömwall \& Granhag 2003.

103 Mann, Vrij \& Bull 2004.

104 M. O'Sullivan e.a., 'Police lie detection accuracy: The effect of lie scenario', Law and Human Behavior 2009, 6, p. 530-538. 
agenten wél aanzienlijk beter in leugendetectie dan de gemiddelde persoon wanneer de scenario's aansluiten op hun werksituatie.

Het gevaar van tunnelvisie ligt tevens op de loer bij het gebruik van profielen en indicatoren. Mensen die niet aan een profiel voldoen of zich onopvallend gedragen maar wel kwade intenties hebben, zullen de dans ontspringen. Dit heeft niet alleen als gevolg dat bepaalde mensen niet worden gepakt, maar ook dat er een scheef beeld staat van wie criminaliteit plegen. Harcourt noemt dit ook wel het ratchet effect. ${ }^{105}$ Door zich te concentreren op een groep binnen een populatie zullen hier buitenproportioneel veel arrestaties uit voortkomen, waardoor het lijkt alsof deze groep daadwerkelijk buitenproportioneel criminaliteit pleegt. Deze gedachtegang wordt goed geillustreerd in een citaat van een oud-politiechef van het Miami-Dade-district in Florida: 'Label me a racist if you wish, but the cold fact is that African Americans comprise [sic] 12\% of the nation's population, but occupy nearly half the state and federal prison cells. African Americans account for 2165 inmates per 100,000 population, versus 307 for non-Hispanic whites and 823 for Hispanics. ${ }^{\text {'106 }}$

Zoals Harris aangeeft, wordt hiermee bedoeld dat, omdat donkere mensen meer criminaliteit zouden plegen, ze ook meer aandacht moeten krijgen. Wanneer men echter alleen let op personen die binnen een profiel passen en niet op de mensen die er buiten vallen, wordt het profiel bevestigd en als het ware een selffulfilling prophecy. Een voorbeeld van tunnelvisie kan worden gevonden in het stuk van Lundman. ${ }^{107}$ Uit de verzamelde gegevens bleek dat minderheden vaker gestopt worden, maar dat bij blanke bestuurders relatief vaker arrestaties werden verricht. Het feit dat uit het overgrote deel van de onderzoeken blijkt dat minderheden nog steeds vaker worden gestopt, zou op tunnelvisie kunnen duiden.

Naast indicatoren die zich richten op een specifiek deel van de bevolking, zijn er ook indicatoren die zo ruim zijn dat ze op bijna iedereen van toepassing kunnen zijn. Voorbeelden hiervan zijn te vinden in het suicide bomber profile zoals dat wordt omschreven door de International Association of Police Chiefs. ${ }^{108}$ In hun profiel is een van de factoren langzaam lopen en veel om zich heen kijken. Dit wordt ook gedaan door de meeste mensen die ergens naar op zoek zijn. Aangezien dit profiel wordt toegepast op vliegvelden, is het waarschijnlijk dat mensen op zoek zijn naar een specifieke balie of gate. Zij zullen daarom al gauw aan deze indicator voldoen. Hetzelfde kan worden gezegd van het strak op een doel aflopen, een andere indicator op de lijst. Mensen die laat zijn voor hun vlucht, zullen snel naar de incheckbalie lopen zodat zij hun vlucht niet missen. Daarnaast worden het angstig kijken en het regelmatig controleren van de tijd of de telefoon genoemd als aandachtspunten. Mensen met vliegangst zullen eerder angstig kijken, en het controleren van de telefoon is voor mensen die hebben afgesproken

105 Harcourt 2006a.

106 D.A. Harris, 'US experiences with racial and ethnic profiling: History, current issues, and the future', Critical Criminology 2006, 3, p. 213-239.

107 R.J. Lundman, 'Driver race, ethnicity, and gender and citizen reports of vehicle searches by police and vehicle search hits: Toward a triangulated scholarly understanding', Journal of Criminal Law and Criminology 2003, 94, p. 309.

108 Centre for Human Rights and Global Justice 2006; Pugliese 2008. 
om samen te reizen ook niet raar. Vorenstaande indicatoren worden gegeven in een lijst met kenmerken waaraan een suicide bomber kan voldoen. Hoewel niet alle kenmerken op de lijst even ruim toepasselijk zijn, wordt het voldoen aan enkele kenmerken op deze manier wel erg gemakkelijk. Dit gaat tegen het punt in dat als grootste voordeel van profielen en indicatoren wordt genoemd: efficiëntie. Wanneer het leeuwendeel van een populatie aan één of meer van de indicatoren voldoet, wordt de groep die gecontroleerd zou moeten worden te groot en is men weer terug bij af. Het is daarom belangrijk dat de indicatoren specifiek en werkbaar blijven, zodat het gevaar van overprofileren vermeden wordt.

Ondanks deze punten van kritiek maken toezichthouders en opsporingsambtenaren graag gebruik van profielen en indicatoren. ${ }^{109}$ Het wordt gezien als een effectieve manier om veel criminelen te pakken. Een voorbeeld hiervan is te vinden in een citaat in het onderzoek van Pratt en Thompson: '(...) but the officers with the highest stats, who find the most bad guys and the guns and the drugs - they're all profiling, every single one of them. ${ }^{110}$

Het is voor organisaties die gebruikmaken van profileren dan ook zaak om dit op een juiste manier te verantwoorden. Wanneer burgers van mening zijn dat een organisatie niet juist of oneerlijk optreedt, doet dit afbreuk aan de legitimiteit van de desbetreffende organisatie. ${ }^{111}$ Dit heeft invloed op de mate waarin men bereid is mee te werken met de organisatie. Hoe minder legitiem een organisatie wordt gezien, hoe minder mensen hun medewerking verlenen. Deze medewerking is voor organisaties die zich bezighouden met opsporing en toezicht wel van belang. Medewerking levert meer en betere informatie op, wat het werk gemakkelijker zal maken.

De discussie in Nederland rondom profileren draagt op het moment niet bij aan het op een juiste manier verantwoorden van profileren. De berichtgeving zoals die te vinden is in de media, geeft een negatieve lading aan de discussie. Dit komt doordat voornamelijk wordt gericht op etnisch profileren. Hierbij wordt impliciet dan wel expliciet geschreven over discriminatie, wat het onderwerp alleen maar gevoeliger en mogelijk zelfs een taboe maakt. Hierbij wordt echter voorbijgegaan aan twee punten. Het eerste punt is de kant van organisaties die gebruikmaken van profilering. Deze kant blijft in de discussie onderbelicht, terwijl het wel van belang is dat hun visie op profileren meer onder de aandacht komt. Zoals namelijk uit internationaal onderzoek blijkt, komt er bij de invulling van discretionaire bevoegdheden veel meer kijken dan alleen etniciteit. Dit sluit aan bij het tweede punt waaraan wordt voorbijgegaan: onderzoek. Het aantal onderzoeken dat in Nederland is uitgevoerd, is zeer beperkt. Toch worden op basis van deze onderzoeken conclusies getrokken die mogelijk niet aansluiten bij de realiteit. Het is daarom van belang dat er meer onderzoek wordt gedaan. Op die manier kan de

109 Lundman 2003; Harris 2006; Pratt \& Thompson 2008.

110 Pratt \& Thompson 2008, p. 629.

111 T.R. Tyler, 'Procedural justice, legitimacy, and the effective rule of law', Crime and Justice 2003, 30, p. 283-357; T.R. Tyler, 'Enhancing police legitimacy', The Annals of the American Academy of Political and Social Science 2004, 1, p. 84-99; T.R. Tyler \& C.J. Wakslak, 'Profiling and police legitimacy: procedural justice, attributions of motive, and acceptance of police authority', Criminology 2004, 2, p. 253-282. 
Tim Dekkers \& Maartje van der Woude

discussie voor beide partijen op een evenwichtige manier en op basis van voldoende informatie worden gevoerd. 